\title{
Philippines
}

\section{Free as a mocking bird}

\author{
Sheila S. Coronel
}

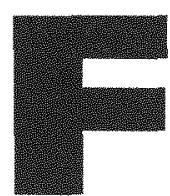

or three days and nights millions of Filipino civilians, led by Catholic nuns armed only with flowers and prayers, faced down the soldiers of their dictator on the streets of Manila as the world watched. As a news story, the knifed-edge stand-off of 1986 was perhaps the most spectacular political tale of the decade. Here was a poor, developing nation cowed by years of authoritarian rule challenging the guns and tanks of the armed forces, women and children packing the crowds with the men as helicopter gunships swirled menacingly overhead. The leader of the opposition was merely a housewife, the widow of the nation's political martyr, Benigno 'Ninoy' Aquino, who had been assassinated after challenging then President Ferdinand Marcos three years earlier. Corazon Aquino, or 'Cory' as she was known, was a reluctant politician, a mother of five who preferred her home life, but had been thrust into the limelight by fate. As the drama played out, culminating in the extraordinary and bloodless defections of key elements of the armed forces to the side of the masses of demonstrators, the international and local media covered developments hour by hour.

But, importantly, the fall of President Marcos in February 1986 was not just a sensational story. The local Filipino media, itself, played a key role in the political confrontation and-it could be argued-tipped the scales in favour of the pro-democracy movement. Like many political confrontations which have followed, such as the middle-class uprising in Thailand in 1992, and the fall of President Soeharto in Indonesia in 1998, the media did not just cover the events, but contributed to the outcome. Two weeks before the final showdown, guerrilla editions of local 
newspapers exposed the massive cheating which Marcos had engineered in national elections, provoking widespread anger and stoking discontent. Since the assassination of 'Ninoy' Aquino in 1983, underground newspapers, and even xerox copies of articles from foreign newspapers, had challenged the views of the censored press, raising awareness that the dictatorship was not indestructable. Then, as the three-day stand-off unfolded Marcos's troops destroyed the transmitter of the Catholic radio station, Veritas, which had been used to rally the people. But, Veritas stayed on the air-broadcasting from a string of safehouses across the citycarrying calls from Cory Aquino and Catholic Cardinal Jaime Sin to mass on the streets. On 25 February 1986 Marcos and his family fled the country on board a US helicopter. After 14 years of dictatorship, the countryand the press-was finally free.

The role played by the anti-Marcos press, and to a lesser extent, independent radio stations, in raising awareness about the excesses of the Marcos government and in encouraging citizens to take part in protests, guaranteed that the media would play a central role in the postdictatorship era. In the last years of the Marcos regime, opposition newspapers reported on anti-government demonstrations, showing Filipinos the extent of the protest movement and emboldening them to organise and participate in mass actions. The coverage of the massive cheating conducted by the government in the February 1986 elections that pitted Marcos against Corazon Aquino stoked the public's ire.

Nowadays, the Philippines boasts a rowdy and vibrant press which thinks of itself as the freest in Asia. With the fall of the Marcos regime, a 14-year-old system of media controls collapsed overnight. Into that vacuum rushed dozens of new newspapers, and radio and television stations, as old Marcos-controlled media outlets folded, or were taken over by the new government. A pluralistic, but somewhat anarchistic, media industry came into being. Today, Filipino journalists are noisy and powerful, their freedoms guaranteed by the constitution and the law. Media exposés make politicians quake, because negative coverage can mean the death of a political career. The media is among the most important influences on voting behaviour, and news anchors and talkshow hosts have become so popular that they have themselves been elected to national office. 
Filipino journalists guard their freedoms fiercely and are strong believers in the adversarial role of the press as watchdog and the Fourth Estate. Thus, the media play an important role in democratic governance by forcing officials and institutions to account for their actions. The downside is that such an adversarial stance has meant sober debate is sometimes difficult in an atmosphere of media hectoring. Moreover, the media has been accused of irresponsible and sloppy reporting and of using their freedoms to exploit the public's taste for the sensational. Intense competition in a crowded market, the lack of trained journalists, 'checkbook' journalism, and the business interests of media owners are among the problems that stunt the professional development of Philippine journalism.

In the late 1990s, those who wish to silence or control the Philippine press do so through market mechanisms, rather than through the strong arm of state control. The more sophisticated methods-including the pulling of advertisements, bribery, and the linking of business success in other spheres to the editorial line of the owner's newspaper-may serve as useful examples of alternative threats to press freedom in the region's new democracies. President Joseph Estrada, for example, has lobbied advertisers and business-owners to put pressure on critical newspapers. For this, he has been widely attacked for muzzling the press, but these actions simply reflect his own understanding that the use of state power directly to control the press in the Philippines is not publicly acceptable.

Despite its excesses, there is strong support for a free press among Filipinos. Any attempt to muzzle the press is resolutely opposed. In part, this is because of fresh memories of the Marcos rule, when the press was the mouthpiece of dictatorship. But it also the legacy of a century-long tradition of a fighting, anti-colonial press.

\section{From anti-colonialism to market forces}

Philippine journalism's first influences were from the 19th century European press, when newspapers were the carriers of political ideas and were at the centre of political activity in the emerging nation states. In the 1880 s and 1890 s, clandestinely distributed newspapers helped raise awareness of the evils of nearly 400 years of Spanish colonial rule, 
germinating the idea of an independent Philippine nation (Corpuz 1989 and Schumacher 1997).

Over the next century, newspapers proliferated during periods of war, revolution and other political upheavals. When the political situation stabilised, many of the papers died. A longer period of relative inactivity followed until the next upheaval-and the next newspaper boom-took place. Successive waves of colonisers-the Spaniards, Americans and Japanese during World War II-used the press to promote the colonial agenda and impose stringent censorship. But a series of anti-colonial movements also employed clandestine newspapers in their fight against the colonial masters. To this day, the samizdat tradition remains strong, with anti-government groups continuing to publish clandestine newsletters.

One lasting and important legacy of 50 years of US colonialism is that of privately owned media outlets competing in a free market. As such there is no tradition of party or state-owned presses in the Philippines. After independence in 1945 and the subsequent establishment of a liberal democratic government, a free press patterned after that of the United States became a powerful weapon wielded by competing political, business and ideological groups to advance their interests and causes (Ofreneo 1986). This changed during the Marcos dictatorship from 197286 , when the media system was controlled by the dictator's family and friends.

The commercial orientation of the Philippine media is most evident in broadcasting. Radio and television have a far shorter history than newspapers, with the first commercial radio station opening in 1930 and the first TV broadcast airing in 1953 (Feliciano and Icban 1967). Unlike other countries in the region, where radio and TV from the beginning were controlled by the state and used for propaganda, information and educational purposes, the broadcast media in the Philippines have always been commercially driven and profit oriented.

This is both a blessing and a curse. On the one hand, the system has meant freedom from state control, except under Marcos. On the other hand, it has also meant that broadcast media content is oriented toward quick profits and is therefore largely fluff and entertainment. Programming is often frivolous and lightweight, with media personalities 
overshadowing media content. The concept of public broadcasting is alien to the Philippines, and the potential of radio and TV for education and inspiring critical thought remains largely untapped.

The Philippine media operate under a lax system of state supervision. The post-Marcos constitution, influenced by that of the United States guarantees free expression. Article IV, Section 4 of the Bill of Rights says 'No law shall be passed abridging the freedom of speech, of expression, or of the press'. No government body oversees or supervises the press. No licence or permit is required to publish a newspaper or magazine. There is no prior review or censorship, and in theory, the press can report on what it wants, subject only to restrictions set by libel, slander and sedition laws.

Broadcasting, however, is subject to greater regulation. As in the preMarcos era, the power to give broadcasting franchises was turned over to Congress. The industry itself was placed under the supervision of the National Telecommunications Commission (NTC). A self-regulatory body for broadcasting set up by Marcos, known by its Tagalog acronym KPB, still exists and continues to set ethical and other standards for both radio and television. The Movie and Television Review Classification Board (MTRCB) has the power to classify, restrict or ban films and TV for public viewing. But, the MTRCB standards are more concerned with decency, violence and contemporary Filipino values than with politics (Stuart 1996).

There is considerable tolerance for critical foreign reporting in the Philippines. Although the constitution bans foreign ownership of the media, foreign newspapers and magazines circulate freely in the country. Only during the Marcos period were foreign publications banned. The wide use of English means that the Philippines is a significant market for English-language foreign publications. TIME, Newsweek, Asiaweek and the Far Eastern Economic Review enjoy brisk sales, although readership is limited to the Manila élite. Foreign TV programs are aired via cable and satellite without prior review or censorship. And, for foreign journalists, the Philippines is probably the easiest country in Asia in which to work. No special licences or permits are required apart from a work permit, and immigration regulations are rarely manipulated to harass journalists. So free are the regulations that many foreign journalists simply enter the country as tourists, then apply for an extension to stay. 


\section{Questionable quality}

New freedoms unleashed by the 1986 uprising gave the media wide latitude to report on events and issues. Media exposés have caused the resignation of officials, raised public awareness about such issues as environmental destruction and the rights of women, and prompted investigations of official abuses and wrongdoing. Investigative reports have a wide audience, and are given prominence on both television and newspapers.

Unfortunately, the media have also used their freedoms to outdo rivals in the race to peddle newspapers and television programs. Intense competition has distorted the conduct of journalism, the content of newspapers, and the programming of radio and television. In the crowded and expanding media market that emerged after the fall of Marcos, the most aggressive media organisations emerged on top (de Jesus 1999). The model, particularly for television, was the United States, a media culture much more familiar in the Philippines than other parts of East Asia because of the American colonial legacy. The expansion of free-wheeling, muckraking type of news organisations was put on hold by Marcos, but they re-emerged once the controls were loosened.

Today, 'TV Patrol', the highest-rating television news program, serves a daily diet of skimpily clad starlets and bloodied corpses. It runs scandalous accounts of the private lives of celebrities and sensationalises crime. As it gobbled up the audience share, the program's rivals were forced to compete by offering more of the same. Competition has resulted in homogeneous reporting and programming because newspapers and broadcast stations produce news reports that are guaranteed to sell.

Another factor hobbling the development of Philippine media is the level of skills. There is a shortage of trained journalists and editors who can raise the quality of reporting and analysis. After the media explosion in 1986, there were not enough experienced journalists to staff newspapers and broadcast agencies. With insufficient on-the-job training, even young journalists are opting out of the profession in search of better-paying careers, contributing to a fast-and damaging-staff turnover at most media outlets.

The petty corruption of journalists by politicians or businessmen who are seeking stories twisted in their favour is almost routine. At press 
conferences swarms of young, poorly paid journalists are frequently handed envelopes of 'taxi' or 'lunch' money for attending. 'Envelopmental journalism', refers to these widely expected envelopes of cash. A 1998 survey of 100 beat reporters conducted by the Philippine Center for Investigative Journalism showed that 71 had been offered money by their sources. Of these, 33 per cent admitted they took the money, with 22 per cent keeping the cash, and 11 per cent turning it over to their editors (Chua and Datinguinoo 1998). The generally low pay of journalists in comparison to other professions is partly responsible for this situation. But other factors, including the reluctance or inability of editors and publishers to enforce ethical standards and the egregious practices of public relations people should also be cited.

Another problem is media ownership, which is concentrated in the hands of wealthy business houses that sometimes use their newspapers to defend and advance their business and political interests. The major dailies and broadcast networks are owned by the giants of Philippine business who operate a wide range of interlocking corporate concerns, including banking, manufacturing, telecommunications and real estate. While most owners rarely intervene in day-to-day editorial decisionmaking, they can nevertheless place clear constraints on the freedom of journalists.

Newspapers have been used by their owners to promote their businesses, denigrate rivals and, on occasion, contest the results of public biddings in which the press proprietors have been losers. At the very least, editors tone down or censor negative reporting on their owners' businesses. Many newspaper proprietors have also tended to take politically safe positions, discouraging reports or exposés that will incur the ire of government. Because business in the Philippines is subject to often whimsical government regulation, newspaper owners who run business empires are vulnerable to government pressure.

In October 1995, the Manila Bulletin ran daily front-page stories criticising the awarding of the purchase of the Manila Hotel to a Malaysian consortium, saying that the historic hotel was part of the 'national patrimony' and should therefore be sold to a Filipino company. The fact was that the Bulletin publisher Emilio Yap, whose other business interests till then lay mainly in banking and shipping, had lost the bid and used his paper to pressure then President Fidel Ramos to reconsider the sale. The 
President did intervene, by asking his aides to work out a compromise with the Malaysians. In the meantime, Yap filed a case in the Supreme Court, using the national patrimony argument, and again, the Bulletin, to argue his point. The Supreme Court, in a controversial decision, decided in Yap's favour.

Likewise, in August and September 1996, the Manila Standard ran editorials and news stories questioning the awarding of the contract for port services at the Subic Freeport to the Hong Kong company Hutchison Ports Philippines Inc. One of the Standard's owners, the Razon family, who runs the International Container Terminal Services Inc. (ICTSI), had lost the bid. The paper campaigned for a reconsideration of the bid, and other papers followed with news reports of the controversy. In the end, as a result largely of the media brouhaha led by the Standard, President Ramos ordered the bidding rescinded (Coronel 1997).

These two cases demonstrate how press proprietors have abused their powers, setting aside the canons of good journalism by using the opinion and news pages of their papers to campaign for their business interests. In both instances, media owners have put the profitability of their business enterprises over the duty of their newspaper to report without fear or favour.

It would be simplistic, however, to say that newspapers are merely mouthpieces of their owners. The reality is more complex. Proprietors intervene in editorial matters to varying degrees and in different ways. Some owners meddle only when their business interests are directly at stake but otherwise leave their editors to decide on what the paper can print-the situation at the Standard. At the Manila Bulletin, on the other hand, the owner takes the place of the editors as gatekeeper of news and information, deciding what readers will find in their morning paper.

There are more liberal-minded owners who give their editors a wider freedom to choose. This is the case with the hard-hitting Philippine Daily Inquirer, whose owners realise that the paper's strength lies in its ability to report critically, even stridently, on current affairs. Some owners may refuse to intercede on behalf of their business interests, but will intervene only when they are under severe pressure from powerful officials to slow down on critical reporting. For example, the Gokongwei family, owner of the Manila Times, allowed its editors to print negative reports about senior government officials. The Gokongweis run a vast business empire that 
includes shopping malls, manufacturing, telecommunications and banking. In July 1999, the family was forced to sell the paper (its editors claim) to appease President Joseph Estrada, who was offended by articles alleging corruption and anomalies in his administration. The paper was sold to a pro-government business group and it is widely believed that the Gokongweis sold it for fear of the government squeezing their other businesses (Singh and Lopez 1999).

\section{An explosion of diversity}

The media explosion that followed the fall of Marcos was largely a response to the public's hunger for news. There are currently ten English and two Tagalog broadsheets published in Manila and circulated throughout the country, compared to three broadsheets during the Marcos era. In addition, there are 17 Manila-based tabloids. Five Chinese-language daily newspapers serve the country's small but influential ethnic Chinese business community. In 1998, some 408 newspapers, mostly weeklies, were distributed in the provinces (Philippine Information Agency 1998).

The biggest and most influential newspaper is the Manila-based, Philippine Daily Inquirer, which began as an opposition newspaper in 1985 and emerged as a market leader combining daring reporting with savvy marketing. The Inquirer, with its adversarial, reporting and strident tone has a loyal following built from its days as an anti-Marcos paper. It has an audited circulation of 240,000 on weekdays and 260,000 on Sundays.

The second biggest paper is the Manila Bulletin, which was founded in 1900 and is the oldest existing newspaper. The Bulletin is conservativethe Inquirer's complete opposite, it avoids controversy and is inclined to print headlines like, 'Schools Open Today.' The Philippine Star, which ranks third, adopted a sober reporting tone since its founding in 1986 but has a stable of star columnists who dish out sizzling political gossip and spicy commentary. Filipino readers love opinion-the more strident, the better. Columnists, rather than editors or reporters, are the crowd-drawers of newspapers.

All but two of the nationally circulated broadsheets are published in English, the language of the educated classes, from which newspaper readership is mainly drawn. Many of the provincial newspapers are in English as well. The biggest chain of community newspapers is run by 
the Sun Star Publications Network based in Cebu, the second largest city after Manila, and owned by the Garcia family, a prominent business and political clan in the Visayas (Chua 1996). The Sun Star has 14 papers throughout the country plus one based in Manila and launched in 1999.

Except for one government-run newspaper chain, all newspapers are privately owned. In the 1980s, journalists and entrepreneurs set up new papers to cater for the demand for news and information. Many of these papers eventually folded or were bought by prominent businesspeople. Within a few years, the owners of the nationally circulated newspapers were mainly businesspeople with a wide range of interests in other sectors of the economy. The exception is BusinessWorld, a respected business newspaper that is 70 per cent owned by its staff. Only four of the dozen broadsheets are profitable, the rest are subsidised by their owners, who finance loss-making newspapers for the prestige and influence they bring, giving credibility to the oft-repeated observation that Philippine newspapers are rich people's toys.

Even though there are close to 30 national newspapers, their combined print run is small and has remained stagnant over the years. It is difficult to estimate exactly what total circulation figures are, as newspapers, with the exception of the Inquirer, refuse to be audited. The informal consensus in the newspaper industry, however, is that the total circulation of the Manila-based broadsheets and tabloids is about 1.5 million. This is small, even allowing for a pass-on readership of 10 persons per newspaper copy, given that the Philippine population breached the 70 million mark in 1998.

In the last decade, while the real growth in terms of audience reach has been in radio and television, newspapers remain important in setting the agenda. The policy-making élite responds to newspapers rather than

\section{Newspaper readership in metro Manila (per cent)}

Broadsheets

Tabloids

Business papers

Foreign newspapers

Source: 1996 Media Index. 
the broadcast media. Moreover, radio and TV take their cue from the broadsheets for reporting on news and public affairs.

Much more than print, the broadcast media experienced dramatic growth since the fall of Marcos. In 1996, the national organisation of broadcasters, the Kapisanan ng mga Brodkaster sa Pilipinas (KBP), reported 517 radio stations throughout the Philippines, of which 283 were AM stations. The bulk of these are commercial radio stations although the government has retained ownership of $32 \mathrm{AM}$ and one FM station. There are eleven religious stations and five educational stations, most of them FM. AM radio is still the dominant format nationwide, except in Metro Manila where FM radio controls 68 per cent of the listeners (KBP Website and AC Nielsen 1997).

The top radio station is DZRH, owned by the once fabulously wealthy Spanish mestizo Elizalde family. DZRH is 60 years old, and has maintained its leadership by combining witty and hard-hitting commentary with onthe-spot news coverage-in contrast to the business clout of the Elizaldes which has been much diminished. The other top-rating AM stations (DZMM, DZRV and DZBB) offer much the same menu-a brew of news, commentary, pop music, and soap. On FM radio, the main fare is music.

Radio is the medium with the greatest reach, with nearly all households owning a radio set. Radio is mainly broadcast in Tagalog and the other Philippine languages, although English is used by FM music stations. On the whole, radio reporting focuses on breaking news. There is no tradition of documentary or in-depth radio reporting in the Philippines. Radio commentators, much like newspaper columnists, have a wide following. Radio commentary, however, is known more for its piercing decibel level rather than its incisiveness or depth.

In 1986, the government took control of the television stations as part of the drive to ferret out the 'illegal wealth' accumulated by Marcos and his associates. To this day, government-appointed boards still run two of six TV stations (RPN-9 and IBC-13) pending their eventual privatisation. While these boards occasionally interfere to ensure that news reporting toes the government line, the stations have much the same commercially oriented programming as the private networks. The government has also kept PTV-4 as the official government TV station, broadcasting shows in support of government programs and initiatives. 
Losing control

\section{Television and radio ownership (per cent)}

Households with radio

Philippines

Metro Manila

Households with TV sets

Philippines

Metro Manila

Source: Media Pulse 1995.

Meanwhile, Channel 2 was handed back to its former owners, the Lopez family, who returned from exile in the United States after the fall of Marcos. The Lopez firm, ABS-CBN, turned Channel 2 into the most popular station through mass-oriented programming in Tagalog. The Lopezes run a diversified business empire that includes, apart from broadcasting, telecommunications, power, water and infrastructure. They also own radio station DZMM, the second largest in the country. In the Philippines, the owners of TV networks also operate radio stations, but they are banned from owning newspapers.

Major television networks

TV network

ABS-CBN (Channel 2)

PTV 4

$\mathrm{ABC}-5$

GMA-7

RPN-9

IBC-13
Radio affiliate Owner

DZMM

DZRB

DWET (FM)

DZBB

DWAN
Lopez family

Official government station

Tan and Yuchengco families Jimenez family Taken over by gov't after 1986

Taken over by gov't after 1986 
In addition to the Manila-based networks which have a national reach, over 150 smaller TV stations operate in the provinces. There are also five UHF channels. Cable television has grown phenomenally in the 1990s, with some 300 cable operators currently operating throughout the Philippines at the end of the decade. The biggest among these is SkyCable, also owned by the Lopez family and accounting for about 60 per cent of some 450,000 cable subscriptions in 1996 (AC Nielsen 1997). The number is expected to double in the next 4 or 5 years, with SkyCable maintaining its lead.

Until quite recently, the television audience was largely middle class and programming consisted mainly of canned US entertainment programs as well as local news and public affairs shows in English. In the 1980s, only a third of all Filipino households owned TV sets. But economic growth in the 1990s spurred the demand for television sets and other consumer goods. In the high-growth years of the 1990s, broadcasting executives estimated that Filipinos purchased some 500,000 new TV sets every year. The consumer boom fuelled an advertising boom that financed the expansion of television networks. In addition, the re-establishment of democracy brought about a keen interest in uncensored TV news and noholds-barred talk shows. A 1997 survey found that 84 per cent of Filipinos watched television, with the figure rising to 97 per cent in the capital (AC Nielsen 1997).

The television explosion caused major shifts in programming. ABS$C B N$ was the first to see the trend. From the bottom of the ratings chart in its first broadcast in October 1986, the station made it to the top in only 6 months. By 1993, it had an audience share of 62 per cent. This phenomenal rise was due largely to how $A B S-C B N$ re-engineered the concept of news and public affairs, producing glitzy, if often trivial, programs that focused on crime, sex and the occult rather than news. Its model was US television's 'infotainment'. ABS-CBN also shifted to Tagalog and produced original programs in the local language instead of relying on shows provided by US distributors. The station was so successful that other networks soon followed suit. In the cut throat competition that ensued, ratings became the sole criterion for programming (Rimban 1996).

Today what are passed off as news and public affairs programs are fast-paced accounts of such wonders as a man who cracks coconuts with his teeth, dwarves who walk on water, or politicians who dance the tango. 
The chat-show format was recast, with starlets, rape victims and criminals crowding out experts and officials. The voice of television was also modified-gone was the sober, serious tone. In its place, the voice has become chatty, and often loud, arrogant, and hectoring.

While the fortunes of ABS-CBN rose, those of the government networks fell, in part because of mismanagement and corruption. Like privately owned networks, government stations are oriented toward profitability rather than education or public service. In the last decade, they have suffered from mediocre programming, diminished numbers of viewers and plummeting profitability (Tirol 1999; Chua 1998).

\section{Continuing constraints}

While the freedom Filipino journalists enjoy is the envy of their colleagues elsewhere in Asia, there are also real impediments on their ability to report freely and responsibly. The most alarming is the high casualty rate of community journalists. Although Manila journalists can accuse the highest officials of grave wrongdoing, there is less tolerance for critical reporting in the provinces, particularly in areas where political bosses or clans have ruled for decades. The New York-based Committee to Protect Journalists puts the number of Filipino journalists killed since 1986 at 33 (Committee to Protect Journalists 1998). It is difficult to say, however, how many of these were killed because of their work. To be sure, a number were victims of the waves of criminality that have swept the country. But many of them were murdered because of their journalism.

One of the recent victims was Ferdinand Reyes, editor of Press Freedom, a weekly in Dipolog City, on Mindanao. Reyes was a crusading journalist who took on local officials, military officers, and even a faraway hotel that had mined the white sands of a local beach. He was only 33 years old when he was shot in his home on 12 February 1996. His killers have not been traced (Severino 1999).

A similar fate befell Nesino Toling, founder and editor of the Panguil Bay Monitor, also on Mindanao island. Toling was gunned down in 1991, just three years after he started his independent paper that ran exposés on the abuses of local officials, including a town mayor whom Toling had accused of stealing steel beams intended to repair a local bridge. The mayor is one of the suspects in the journalist's murder which, to this day, nearly 
a decade later, remains unsolved (Rimban 1999a). Certainly, the impunity with which those wishing to silence journalists can operate contributes to the rising casualty count. The judicial and law-enforcement system in the Philippines is weak and prone to pressure from the wealthy and powerful, providing little protection for citizens, journalists included.

Philippine libel laws, which are patterned after those of the United States, are less restrictive than those elsewhere. But this has not stopped officials and other parties who feel offended by critical reporting from filing harassment suits against journalists. Libel in the Philippines is both a civil and a criminal offense, with penalties ranging from six months to six years. Journalists can be jailed for what they have written, and the law provides that even publishers, business managers and the entire cast of editors in a newspaper may be included in a case.

Fortunately, Philippine courts have tended to rule in favour of the freedom of journalists to report and comment. The Supreme Court has held that the media

should be given such leeway and tolerance as to enable them to courageously and effectively perform their important role in our democracy. In the preparation of stories, press reporters and editors usually have to race with their deadlines, and consistently with good faith and reasonable care, they should not be held to account, to a point of suppression, for honest mistakes or imperfections in the choice of words (Coronel 1991).

In 1987, a Philippine Star columnist was sued by the then President Aquino, who was also Commander-in-Chief of the Armed Forces, for reporting that she had been hiding under her bed as rebel troops surrounded the Palace, in one of the bloodiest coup attempts of her first years in power. It was a pivotal moment for Philippine politics which had been marked by persistent questioning of the ability of a former housewife to run the country, and command the armed forces. For Cory the suit was a deeply personal battle against her detractors. The lower court ruled in her favour but the Supreme Court later reversed the decision.

In March 1999, President Estrada sued the Manila Times for P101 million in damages for reporting that he was an 'unwitting godfather' to a supposedly anomalous power contract. Estrada withdrew the suit after the owner of the Manila Times apologised for the 'anxiety' caused by the story, although the paper stood by its report. 


\section{Losing control}

While many high-profile cases are withdrawn before they get to court, lawsuits filed against small newspapers and little-known journalists are often tried. Court cases are time consuming and expensive and often a damper on critical reporting. They can also lead to prison sentences. In 1997, journalist Joy Francisco, editor of a small weekly in Cotabato, was jailed after a local revenue official filed a case against her (Francisco 1997). The case had not yet been processed by the prosecutor but a warrant was already issued for her arrest, in clear defiance of court procedure. This was a case of 'local bosses' putting pressure on the courts, and journalists like Francisco, who work out of the protection of the limelight, are the most vulnerable.

The threat of advertising withdrawals in retaliation for adverse reporting is commonplace. Television, which absorbs the largest share of advertising revenue, tends to be the most cautious about incurring the ire of advertisers. One of the largest advertisers is beer and tobacco magnate Lucio Tan whose firms spent some P1.6 billion in advertising in 1997. TV advertising managers say that Tan's policy is to air commercials only in programs considered friendly to the tycoon - a man who has been accused of tax evasion and of being a Marcos crony. In 1996, when ABS-CBN anchor Korina Sanchez read a news report detailing tax evasion charges against Tan, the businessman's tobacco company promptly pulled out its ads from her program (Rimban 1999b).

Tan's case is not unique. In 1997, the Philippine Long Distance Telephone Co. (PLDT), which for years ran a profitable telecommunications monopoly, withdrew its ads from a TV program which ran a story on how the firm was delaying interconnection with rival telephone companies (Rimban 199b). PLDT also pulled out its ads from Business World in 1993, after the paper ran critical reports about its monopolistic practices (Coronel 1998).

Article III(7) of the Philippine Constitution recognises 'the right of the people to information of matters of public concern'. It states that 'access to official records and documents, and papers pertaining to official acts, transactions, or decisions as well as to government research data used as basis for policy development, shall be afforded the citizen'. Other pertinent laws guarantee public disclosure of information and make it the duty of public officials to release information. 
As a whole, Filipino officials tend to be more cooperative about releasing documents and information than many officials elsewhere in the region. Some government agencies even entertain information requests over the phone, although most require a written letter of request. But problematic areas remain. Officials are often not cooperative about releasing sensitive information, especially in the provinces. They normally delay disclosure for weeks or months or else provide only incomplete documents.

The quality of information that is made public often falls short of journalists' expectations. Partly this is because government recordkeeping is bad, but it is also because disclosure laws are sometimes a disincentive to filing complete or truthful information. For example, all government officials are required to file statements of assets and to release these to the public. But because journalists have used these statements to write reports on corruption or the accumulation of ill-gotten wealth, officials have tended to fudge their declarations or to leave out assets that may rouse the suspicions of inquisitive reporters.

Moreover, while there is a constitutional provision that guarantees disclosure, there is no freedom of information law that will ensure that the constitutional mandate is implemented. There is no system of appeal if requests for disclosure are turned down. Recourse can only be made through the courts and that means expensive and time-consuming litigation. The Philippine judicial system is clogged with cases and lawsuits often take years before they are decided.

\section{Some conclusions}

The problems of the Philippine media have less to do with state control than with the anarchy of a crowded and competitive market. Respect for a free press is institutionalised in the constitution and the law, and is deeply ingrained in the political culture. Most Filipino journalists agree that the killings of their colleagues in the provinces do not form a pattern of state repression. Rather, they appear to be isolated incidents that have more to do with the configurations of power and the breakdown of law and order in specific localities. In this sense, the problem is a weak state unable to enforce the rules and to protect its citizens. 
It is interesting to note that in the late 1990s, those who wished to control or silence the press were using market forces rather than state control. Increasingly sophisticated methods of controlling or influencing the media may serve as a good example of the novel forms the threats to press freedom can take in new democracies. One is 'envelopmental journalism' or the systematic bribing of journalists by business and government agencies to ensure favourable coverage. It is also well known that some journalists are on the monthly payroll of politicians or private companies.

Special pay-offs are made during periods like elections or the launching of new products. The bribes are so discreet that they are now often coursed through automated teller machines, so as not to leave a paper trail. Instead of openly distributing envelopes of cash or handing out checks, more sophisticated PR practitioners have resorted to depositing the bribes directly in the bank accounts of journalists, or more discreetly, the accounts of their friends or relatives (Hofileña 1998). But in whatever form the pay-offs are made, they result in some stories being silenced while others are unduly highlighted.

Another way to muzzle the press is by pressuring media proprietors. Ownership is the true chink in the armor of the Philippine media. The fact that most of the media are owned by big business houses makes them especially vulnerable to intervention from government or business. At the giant $\mathrm{ABS}-\mathrm{CBN}$, for example, the news department's unwritten rules say that topics that have some sort of connection with the extensive business holdings of the Lopez family, the network's owner, have to be treated carefully. This becomes difficult because the Lopezes are involved in, among other things, public utilities-from electric power to telephones to water. Moreover, the recent marriage of a member of the family to a daughter of President Estrada means that the network has to tread carefully when reporting on the president as well. In the Philippines, family and business interests often overcome most other considerations.

Neither former Presidents Aquino and Ramos exploited the vulnerability of media owners. But Estrada, angry at a barrage of negative media reporting, has made his displeasure known to media proprietors and has not baulked at pressuring them to tone down critical coverage. In February 1999, he criticised the owner of the Standard on the telephone 
for a news report that insinuated that he was using a BMW that belonged to a congressman known for brokering shady deals. Enrique Razon Jr., who owns 50 per cent of the paper, was contrite and offered to fire his editors. After all, he runs a company that has cornered major contracts for servicing ports throughout the country (Coronel 1999).

Since the re-establishment of democracy in 1986, Estrada is the first Philippine president to employ non-state mechanisms systematically to clamp down on a critical press. In addition to putting pressure on the businesses of media proprietors, the president's open encouragement of an advertising boycott of the Inquirer was decried by citizens and media groups as a threat to press freedom. The manipulation of advertising budgets is another way in which the proxy battle between the government and the press is being waged.

Estrada, himself a former film star and movie producer, encouraged movie producers in July 1999 not to place ads in the Inquirer, which he said was unfairly critical of his administration. In addition, big companies with huge advertising budgets and sympathetic to the President have withdrawn ads from the paper (Asiaweek, 6 August 1999).

All these methods-bribery, pressure on owners and the withdrawal of advertising-silence the press in various ways and reduce the diversity of voices that can be heard by the public. The new-generation tactics, however, involve the 'privatisation' of media repression, allowing Estrada to argue that the government is not clamping down on the press. Rather than state mechanisms, so-called market forces are being used to silence critical reporting.

These developments have divided the journalist's community. Some newspapers and journalists argue that ad pullouts and the sale of newspapers are private initiatives that do not constitute a threat to press freedom. Others, however, are more critical of the government and accuse it of conducting a sustained campaign to intimidate the media. They think media corruption is insidious and harmful because it hampers the media's capability to report freely and responsibly.

There has been a public outcry about Estrada's attempts to clamp down on the press. Even if divided, Filipino journalists can rely on broad public support to defend a free press. But journalists also have to show greater responsibility if they want continuing public sympathy. There have been 
some attempts to address the problems of ethics and professionalism through a Codes of Ethics and training programs that improve investigative and reporting skills. But most observers of the Philippine media think these efforts do not suffice. After 12 years of democracy, they realise that it takes time- and great effort-to build a truly professional corps of journalists. But they also know that professional journalism is possible only if the press is free.

\section{Media organisations}

- Kapisanan ng mga Brodkaster sa Pilipinas (KBP or the Association of Filipino Broadcasters). Formed in 1973, shortly after the declaration of martial law, the KBP is the trade organisation for the broadcast media. At the outset, the KBP-supposedly a self-regulatory body composed of industry representatives-was a fiction to mask government control of broadcasting. But the KBP was able to overcome initial difficulties and contribute to the professionalisation of broadcasting by drafting a Code of Ethics that became the basis for self-regulation. It also

\section{Major Philippine newspapers}

Abante +

BusinessWorld

bworld.com.ph

Dyaryo Uno +

Kabayan+

Malaya

Manila Bulletin

www.mb.com.ph

Manila Standard

People's Journal*+

Philippine Daily Inquirer

www. inquirer.net

Philippine Star

Sun Star

www.philstar.com

Tempo*

Today

www2.sunstar.com.ph

www.today.com.ph

Note: *Tabloid; + Tagalog 
cooperates with the government in airing 'developmental messages' on such issues as AIDS awareness, drug prevention and other government programs. The KBP's Standards Authority acts as a quasijudicial body and can impose fines and reprimands for violation of its code on such matters as decency and violence. It also sets a cap on the volume of advertising per broadcast hour. Website: www.kbp.org.ph

- Philippine Press Institute (PPI). The association of newspaper publishers was formed in 1964 to represent the interests of the newspaper industry, to raise ethical and professional standards, and to provide support for community newspapers that make up the bulk of the institute's membership. The PPI set up a Press Council in 1965 to investigate ethical violations. Both the PPI and the Press Council closed down with the declaration of martial law. The PPI was reopened in 1987 and the Press Council was reconvened in 1993 but with a much more focused scope to investigate complaints involving the right to reply. The PPI has drafted a Code of Ethics and conducts regular seminars to upgrade ethical and professional standards. Website: www.pressasia.org/PFA/members/index.html/

- National Press Club (NPC). An association of more than 1,500 individual reporters, the NPC was formed in 1954. Over the years, depending on the inclinations of its leadership, the NPC has sometimes taken a stand on press freedom and ethical issues but in recent years has become a purely social club.

- Center for Media Freedom and Responsibility (CMFR). Founded in 1989 as a private, independent initiative to monitor the media, the CMFR publishes a quarterly review of the press, the Philippine Journalism Review. It also conducts seminars and workshops on issues concerning the media and brings journalists together for consensusbuilding discussions. The Center is a non-profit organisation with a board of trustees composed of academics, journalists and businesspeople. Website: www.cmfr.com.ph/

- Philippine Center for Investigative Journalism (PCIJ). An independent, non-profit media organisation that specialises in investigative reporting, the PCIJ was founded in 1989 by journalists who saw the need for newspapers and broadcast agencies to go beyond routine, day-to-day reportage. The $\mathrm{PCIJ}$ was set up to promote 
investigative reporting and to create a culture within the Philippine media. The Center funds investigative projects, publishes books on current issues and manuals on reporting, and publishes a quarterly investigative reporting magazine. It also organises training seminars for journalists in the Philippines and the region. Website: www.pcij.org/ 